\title{
Isolated Adrenocorticotropic Hormone Deficiency with Transient Thyroiditis Inducing an Adrenal Crisis
}

\author{
Tetsuya Hiraiwa $^{a}$ Daisuke Furutama ${ }^{a}$ Sadaki Sakane ${ }^{b}$ Mitsuru Ito ${ }^{a}$

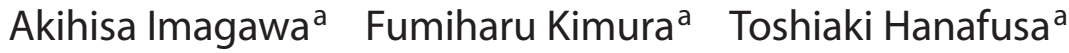

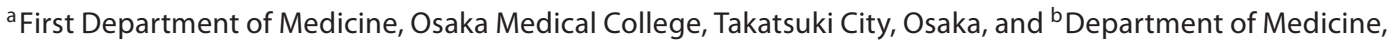 \\ Hirakata City Hospital, Hirakata City, Osaka, Japan
}

\section{Key Words}

Isolated adrenocorticotropic hormone deficiency •

Metabolic encephalopathy · Transient thyroiditis · Adrenal crisis $\cdot$ Hyponatremia

\begin{abstract}
Objective: It was the aim of this study to describe a patient with isolated adrenocorticotropic hormone deficiency presenting with a variety of involuntary movements who developed an adrenal crisis due to transient thyroiditis. Clinical Presentation and Intervention: A 61-year-old man was hospitalized with a variety of involuntary movements that were suspected manifestations of metabolic encephalopathy. After admission, his general status rapidly deteriorated to a life-threatening condition that included a degree of hyponatremia. The hyponatremia and metabolic encephalopathy provided clues toward a definitive diagnosis. After corticosteroid and sodium supplementation improved the status of the patient, endocrinological examinations revealed that he suffered from isolated adrenocorticotropic hormone deficiency followed by transient thyroiditis that induced an adrenal crisis. Conclusion: This case emphasizes the importance of considering hypoadrenalism when encountering hyponatremia or metabolic encephalopathy of unknown etiology.

Copyright $\odot 2007$ S. Karger AG, Basel
\end{abstract}

\section{Introduction}

A diagnosis of isolated adrenocorticotropic hormone deficiency (IAD) is often difficult, as the disease has atypical manifestations and is occasionally accompanied by neurological symptoms [1]. An adrenal crisis is a lifethreatening condition that results from a failure to compensate for chronic or relative hypoadrenalism, and in the majority of cases, is precipitated by a stressful event [2]. In this paper, we describe a patient with IAD who presented with a variety of involuntary movements, and subsequently, developed an adrenal crisis due to transient thyroiditis.

\section{Case Report}

A 61-year-old man was referred to Osaka Medical College Hospital because of worsening of involuntary movements. Initially, he experienced shoulder stiffness and pain, with these symptoms spreading to the extremities and worsening gradually over a 2-month period. During the next month, he developed a tremor and anorexia and lost $7 \mathrm{~kg}$ in body weight, leading to admission to another hospital. However, the origin of the symptoms could not be identified, and therefore, the patient was transferred to the Division of Neurology at our hospital. At the age of 41 years, he had gastrectomy due to a gastric ulcer and an unremarkable family history.

\section{KARGER}

Fax +4161306 1234

E-Mail karger@karger.ch

www.karger.com
(C) 2007 S. Karger AG, Basel

1011-7571/07/0163-0230\$23.50/0

Accessible online at:

www.karger.com/mpp
Tetsuya Hiraiwa

First Department of Medicine

Osaka Medical College, 2-7 Daigakumachi

Takatsuki City, Osaka 569-8686 (Japan)

Tel. +81 72683 1221, Fax +81 72683 1801, E-Mail in1149@poh.osaka-med.ac.jp 
Table 1. Clinical course of biochemical tests

\begin{tabular}{rllll}
\hline & $\begin{array}{l}\text { Serum } \\
\text { creatinine } \\
\text { mg/dl }\end{array}$ & Serum Na & $\begin{array}{l}\text { Serum } \\
\text { osmolality } \\
\text { mosm/kg }\end{array}$ & $\begin{array}{l}\text { Urine } \\
\text { osmolality } \\
\text { mosm/kg }\end{array}$ \\
\hline Day & & & & \\
2 & 1.01 & 127 & 260 & 361 \\
5 & 0.89 & 115 & 239 & 367 \\
6 & 0.87 & 121 & 247 & 316 \\
8 & 0.68 & 131 & 276 & 349 \\
10 & 0.59 & 136 & 276 & 362 \\
16 & 0.64 & 136 & 279 & 278 \\
\hline Reference range & $0.50-1.20$ & $135-148$ & $285-295$ & $50-1,400$ \\
\hline
\end{tabular}

On physical examination, his height was $162 \mathrm{~cm}$, his weight 55 $\mathrm{kg}$, blood pressure $124 / 84 \mathrm{~mm} \mathrm{Hg}$, pulse rate 72 beats/min and temperature $35.7^{\circ} \mathrm{C}$. The thyroid was neither palpable nor tender. An operative scar was observed on the midline of the upper abdomen. Neither skin pigmentation nor loss of axillary or pubic hair was evident. On neurological examination, his consciousness was clear without irritation, and no abnormalities of the cranial or sensory nerves were evident. The patient presented with muscle rigidity, flexion contracture in the extremities and increased deep tendon reflexes in the upper and lower limbs. Bilateral Wartenberg and Babinski signs were observed. Involuntary movements included fine and postural tremor of the extremities, asterixis, muscle twitching and patellar clonus-like knee motions in the forced flexion position.

The results of routine laboratory analyses were as follows: white blood cell count $6,040 / \mu$ l (neutrophils $56.1 \%$, eosinophils $4.8 \%$, basophils $0.7 \%$, lymphocytes $25.4 \%$, monocytes $11.4 \%$ ), total serum protein $5.5 \mathrm{~g} / \mathrm{dl}$ (reference range 6.3-8.0), albumin 3.2 $\mathrm{g} / \mathrm{dl}$ (reference range 3.5-5.0), aspartate aminotransferase $68 \mathrm{U} / \mathrm{l}$ (reference range 10-35), total cholesterol $114 \mathrm{mg} / \mathrm{dl}$ (reference range 140-220), serum glucose $85 \mathrm{mg} / \mathrm{dl}$ (reference range 60-90), serum sodium $127 \mathrm{mEq} / \mathrm{l}$ (reference range 135-148), serum potassium $4.7 \mathrm{mEq} / \mathrm{l}$ (reference range 3.6-5.2), serum corrected calcium $9.5 \mathrm{mg} / \mathrm{dl}$ (reference range 8.4-10.2), serum magnesium 1.7 $\mathrm{mg} / \mathrm{dl}$ (reference range 2.0-2.8), alkaline phosphatase $300 \mathrm{U} / \mathrm{l}$ (reference range 100-330), and C-reactive protein $2.46 \mathrm{mg} / \mathrm{dl}$ (reference value $<0.25$ ). Radiological examinations of the head using computed tomography and magnetic resonance imaging demonstrated previous lacunar infarctions in the basal ganglia.

On the 5th hospital day, the patient's consciousness deteriorated rapidly and his neurological symptoms were exacerbated. He also developed a fever of $37.9^{\circ} \mathrm{C}$, with a blood pressure of $136 / 80 \mathrm{~mm} \mathrm{Hg}$ and obvious symptoms of dehydration that included dry skin, a dry oral cavity and decreased turgor. Arterial blood gas analysis showed a $\mathrm{pH}$ of 7.436, $\mathrm{pO}_{2}$ of 96.4 Torr, $\mathrm{pCO}_{2}$ of 34.1 Torr and a base excess of $-0.1 \mathrm{mEq} / \mathrm{l}$. Laboratory analyses were repeated with the following results: serum glucose level 70 $\mathrm{mg} / \mathrm{dl}$, serum sodium level $115 \mathrm{mEq} / \mathrm{l}$, serum corrected calcium $9.6 \mathrm{mg} / \mathrm{dl}$, urine sodium level $112 \mathrm{mEq} / \mathrm{l}$ and total urine sodium excretion $257 \mathrm{mEq} /$ day. These findings indicated that urinary sodium excretion had not decreased despite the presence of hyponatremia. At this point, although it was suspected that he had hypoadrenalism, it was unclear if the patient's pathophysiology was an exacerbation of a neurological disorder or an adrenal crisis presenting as metabolic encephalopathy. He received prednisolone (10 mg/day) and a continuous sodium infusion of 35-135 $\mathrm{mEq} / \mathrm{l}$ from the 5 th hospital day on, for a total sodium volume of between 300 and $400 \mathrm{mEq} /$ day for 3 days. The serial changes of the biochemical tests from days 2-16 are presented in table 1 .

Endocrinological assessment revealed secondary hypoadrenalism due to IAD, with plasma levels of adrenocorticotropic hormone $(\mathrm{ACTH})<5 \mathrm{pg} / \mathrm{ml}$ (reference range 9-52), cortisol $2.6 \mu \mathrm{g} / \mathrm{dl}$ (reference range 4.0-18.3), aldosterone $<10 \mathrm{pg} / \mathrm{ml}$ (reference range 29.9-159) and dehydroepiandrosterone sulfate $150 \mathrm{ng} / \mathrm{ml}$. A rapid ACTH test using an intravenous injection of ACTH (250 $\mu \mathrm{g})$ demonstrated no response to cortisol as the level remained basically the same at $0 \mathrm{~min}(16.6 \mu \mathrm{g} / \mathrm{dl})$ and at $60 \mathrm{~min}(14.9 \mu / \mathrm{dl})$. A 3-day ACTH infusion test using intramuscular injections of long-acting ACTH exhibited low baseline urinary levels of 17-hydroxycorticosteroid, which increased in a stepwise manner during the infusion. Urine levels of 17-hydroxycorticosteroid on days 1 (control), 2 (control), 3 (250 $\mu \mathrm{g}$ of ACTH), 4 (250 $\mu \mathrm{g}$ of ACTH) and 5 (250 $\mu$ g of ACTH) were 3.9, 3.8, 9.2, 26.3 and $33.6 \mathrm{mg} /$ day, respectively (reference range 3.4-12.0). Other hormone levels were as follows: growth hormone $6.08 \mathrm{ng} / \mathrm{ml}$, insulin-like growth factor-1 $46 \mathrm{ng} / \mathrm{ml}$ (reference range 42-250), 1,25-(OH) 2 vitamin D $3.0 \mathrm{pg} / \mathrm{ml}$ (reference range 20-60) and high-sensitivity parathyroid hormone $240 \mathrm{pg} / \mathrm{ml}$ (reference range 160-520). A corticotrophin-releasing hormone $(\mathrm{CRH})$ test demonstrated no response to ACTH (table 2). $\mathrm{CRH}$, thyrotropin (TSH)-releasing hormone and luteinizing-hormone-releasing hormone tests were performed simultaneously, using intravenous injections of either $\mathrm{CRH}$ $(100 \mu \mathrm{g})$, TSH-releasing hormone $(500 \mu \mathrm{g})$ or luteinizing-hormone-releasing hormone $(100 \mu \mathrm{g})$. The results of these tests are presented in table 2 . On the basis of these results, the patient was diagnosed with IAD, and it was concluded that the low response to TSH had resulted from an earlier period of thyrotoxicosis. Anterior pituitary antibodies, assessed by immunofluorescence using AtT-20 (mouse ACTH secreting cell) as the antigen, were not detectable. Pituitary magnetic resonance imaging demonstrated normal findings, and an empty sella was not evident.

On the 5th hospital day, thyroid function testing and autoantibody screening demonstrated levels of TSH $<0.03 \mathrm{mU} / \mathrm{l}$ (reference range $0.60-5.30$ ), free thyroxine $5.91 \mathrm{ng} / \mathrm{dl}$ (reference range 
Table 2. Provocative tests to assess pituitary function

\begin{tabular}{lccccccc}
\hline & \multirow{2}{*}{$\begin{array}{l}\text { Reference } \\
\text { range }\end{array}$} & \multicolumn{2}{l}{ Time } & & & \\
\cline { 3 - 7 } & & $0 \mathrm{~min}$ & $30 \mathrm{~min}$ & $60 \mathrm{~min}$ & $90 \mathrm{~min}$ & $120 \mathrm{~min}$ \\
\hline $\mathrm{ACTH}, \mathrm{pg} / \mathrm{ml}$ & $9-52$ & $<5$ & $<5$ & $<5$ & $<5$ & $<5$ \\
$\mathrm{Cortisol}, \mu \mathrm{g} / \mathrm{dl}$ & $4.0-18.3$ & 14.9 & 12.9 & 13.9 & 13.7 & 11.9 \\
$\mathrm{TSH}, \mu \mathrm{U} / \mathrm{ml}$ & $0.60-5.30$ & 0.17 & 0.51 & 0.47 & 0.38 & 0.31 \\
$\mathrm{PRL}, \mathrm{ng} / \mathrm{ml}$ & $1.5-9.7$ & 5.3 & 26.0 & 15.0 & 10.0 & 8.1 \\
$\mathrm{LH}, \mathrm{mU} / \mathrm{ml}$ & $1.1-8.8$ & 6.0 & 26.9 & 26.6 & 22.6 & 20.3 \\
$\mathrm{FSH}, \mathrm{mU} / \mathrm{ml}$ & $1.8-15.0$ & 15.3 & 22.7 & 25.2 & 24.1 & 24.4 \\
\hline
\end{tabular}

$\mathrm{TSH}=$ Thyrotropin; $\mathrm{PRL}=$ prolactin $; \mathrm{LH}=$ luteinizing hormone; $\mathrm{FSH}=$ folliclestimulating hormone.
Table 3. Clinical course of thyroid function tests

$\begin{array}{lll}\mathrm{FT}_{4} & \mathrm{FT}_{3} & \mathrm{TSH} \\ \mathrm{ng} / \mathrm{dl} & \mathrm{pg} / \mathrm{ml} & \mathrm{U} / \mathrm{l}\end{array}$

\begin{tabular}{rllc}
\hline \multicolumn{1}{l}{ Day } & & & \\
1 & UD & UD & UD \\
5 & 5.91 & 7.48 & $<0.03$ \\
10 & 2.83 & 3.64 & $<0.03$ \\
23 & 1.43 & 2.46 & $<0.03$ \\
36 & 0.71 & UD & 0.17 \\
54 & 0.35 & UD & 22.77 \\
\hline Reference range & $0.90-2.00$ & $1.50-4.50$ & $0.60-5.30$ \\
\hline
\end{tabular}

$\mathrm{FT}_{4}=$ Free thyroxine; $\mathrm{FT}_{3}=$ free triiodothyronine; $\mathrm{UD}=$ undetermined.
$0.90-2.00$ ), free triiodothyronine $7.48 \mathrm{pg} / \mathrm{ml}$ (reference range $1.50-4.50$ ), TSH receptor antibody $2.3 \%$ (reference value $<15$ ), TSH receptor-stimulating antibody $113 \%$ (reference value $<180$ ), thyroglobulin antibody $1.2 \mathrm{U} / 1$ (reference value $<0.3$ ), and thyroperoxidase antibody $<0.3 \mathrm{U} / 1$ (reference value $<0.3$ ). On the 10 th hospital day, thyroglobulin concentration was $117.0 \mathrm{ng} / \mathrm{ml}$ (reference value $<45$ ). The patient's thyroid function normalized gradually without antithyroid medication. On the 36th hospital day, the level of free thyroxine decreased below normal range, and normal findings on the thyroid ultrasonography were subsequently confirmed. The series of thyroid function tests (table 3) and the presence of thyroglobulin antibody demonstrated that the patient developed transient thyroiditis (Hashimoto's thyroiditis), although past reports have suggested that TSH secretion is increased in adrenal insufficiency in the absence of thyroid disease [3]. Finally, $50 \mu \mathrm{g}$ of levothyroxine by oral administration was started on the 79th day because of continuous hypothyroidism.

On the basis of these findings, we concluded that the patient had IAD and developed transient thyroiditis that precipitated an adrenal crisis which, in retrospect, manifested as a metabolic encephalopathy. Following treatment with corticosteroid and sodium supplementation, the patient recovered from the neurological symptoms and hyponatremia, and there was a gradual im- provement in his alimentary condition. Therefore, the dose of prednisolone was decreased from 10 to $5 \mathrm{mg}$ on the $62 \mathrm{nd}$ day at the outpatient clinic and was changed to $20 \mathrm{mg}$ of hydrocortisone on the 79th day.

\section{Discussion}

This is the first report of a patient with IAD who developed an adrenal crisis due to transient thyroiditis. In this patient, an increase in autoimmune activity due to hypoadrenalism resulted in the development of transient thyroiditis. Clinical evidence from 4 cases of chronic or relative hypoadrenalism followed by silent thyroiditis has been reported to date [4-7].

Cortisol levels should be measured in cases of hyponatremia of unknown etiology, as low sodium levels have been reported in $88 \%$ of patients with primary adrenal insufficiency and $28 \%$ of IAD patients [8]. The majority of the symptoms of hypoadrenalism, including neurolog- 
ical symptoms, are nonspecific. The causes of hyponatremia are also nonspecific, numerous and often difficult to identify, with symptoms and signs varying from subtle to extreme. Accordingly, when hypoadrenalism is the cause of the disorder, the correct diagnosis requires the use of hormonal and/or dynamic tests [9].

Recognition of hypoadrenalism presenting as metabolic encephalopathy is very important. Neurological symptoms are sometimes a feature of general medical disorders and are collectively referred to as 'metabolic encephalopathy'. These symptoms include impaired consciousness, global brain stem signs, pathological reflexes, abnormality of muscle tone and a variety of involuntary movements, such as tremors and multifocal myoclonus [10]. Hypoadrenalism including IAD is sometimes accompanied by neurological symptoms [11]; however, a diagnosis of hypoadrenalism is not easy to make based solely on accompanying neurological symptoms.

There is a possibility that a low dose of oral prednisolone and $\mathrm{Na}$ infusion, which mildly elevated serum sodium concentration, are appropriate for this patient, al- though the ordinary practice is a large dose of intravenous hydrocortisone. Rapid correction of serum sodium in patients with hypoadrenalism can cause a complication of central myelinolysis [12]. In the present case, the rates of serum sodium correction during the initial 3 days and subsequent 2 days were $5-6$ and $2.5 \mathrm{mEq} / \mathrm{l}$, respectively, during a 24 -hour period (table 1). Between the 9th and the 10th hospital day, the patient's general condition was greatly improved, and the results of ACTH and cortisol levels of collected blood on the 6th hospital day revealed hypoadrenalism.

\section{Conclusion}

We present a patient with IAD who developed an adrenal crisis due to transient thyroiditis. This case emphasizes the importance of considering hypoadrenalism when encountering hyponatremia or metabolic encephalopathy of unknown etiology.

\section{References}

$\checkmark 1$ Stacpoole PW, Interlandi JW, Nicholson WE, Rabin D: Isolated ACTH deficiency; a heterogeneous disorder. Critical review and report of four new cases. Medicine 1982;61: 13-24.

$>2$ Gilliland PF: Endocrine emergencies. Adrenal crisis, myxedema coma, and thyroid storm. Postgrad Med 1983;74:215-220, 225227.

$\checkmark 3$ Nicoloff JT, Fisher DA, Appleman MD Jr: The role of glucocorticoids in the regulation of thyroid function in man. J Clin Invest 1970;49:1922-1929.

$\checkmark 4$ Takasu N, Komiya I, Nagasawa Y, Asawa T, Yamada T: Exacerbation of autoimmune thyroid dysfunction after unilateral adrenalectomy in patients with Cushing's syndrome due to an adrenocortical adenoma. $\mathrm{N}$ Engl J Med 1990;322:1708-1712.
5 Yamakita N, Sakata S, Hayashi H, Maekawa $\mathrm{H}$, Miura K: Case report: silent thyroiditis after adrenalectomy in a patient with Cushing's syndrome. Am J Med Sci 1993;305:304306.

6 Parker M, Klein I, Fishman LM, Levey GS: Silent thyrotoxic thyroiditis in association with chronic adrenocortical insufficiency. Arch Intern Med 1980;140:1108-1109.

7 Peterson RE: The influence of the thyroid on adrenal cortical function. J Clin Invest 1958; 37:736-743

8 Carroll PB, McHenry L, Verbalis JG: Isolated adrenocorticotrophic hormone deficiency presenting as chronic hyponatremia. N Y State J Med 1990;90:210-213.
$>$ Milionis HJ, Liamis GL, Elisaf MS: The hyponatremic patient: a systematic approach to laboratory diagnosis. CMAJ 2002;166:10561062.

10 Kunze K: Metabolic encephalopathies. J Neurol 2002;249:1150-1159.

11 Sekijima Y, Hoshi KI, Kasai H, Okada M, Namiki S, Ohta K, Nakano T, Hirayama J, Ikeda SI: Three patients with isolated adrenocorticotropin deficiency presenting with neuroleptic malignant syndrome-like symptoms. Intern Med 2001;40:510-514.

12 Lasheen I, Doi SA, Al-Shoumer KA: Glucocorticoid replacement in panhypopituitarism complicated by myelinolysis. Med Princ Pract 2005;14:115-117. 